\title{
Feeding habits of the Atlantic bluefin tuna, Thunnus thynnus (L. 1758), in the central Mediterranean Sea (Strait of Messina)
}

\author{
Pietro Battaglia • Franco Andaloro - Pierpaolo Consoli • \\ Valentina Esposito • Danilo Malara • Simona Musolino • \\ Cristina Pedà $\cdot$ Teresa Romeo
}

Received: 20 October 2011/Revised: 9 April 2012/ Accepted: 16 April 2012/Published online: 1 May 2012 (C) Springer-Verlag and AWI 2012

\begin{abstract}
The study of feeding habits of the Atlantic bluefin tuna was carried out in 123 specimens, ranging from 115 to $222 \mathrm{~cm}$ fork length (FL) and collected during spring seasons of 2010 and 2011 in the central Mediterranean Sea (Strait of Messina). The analysis of stomach contents allowed us to identify 91 taxa of prey items, mainly belonging to Teleostea (54), Cephalopoda (20) and Crustacea (13). The percentage of index of relative abundance (IRI) shows the highest values for the myctophid Hygophum benoiti $(\% I R I=22.854)$ and the stomiid Chauliodus sloani $(\%$ IRI $=15.124)$, followed by the oegopsid squid Illex coindetii $(\% I R I=14.316)$. The broad spectrum of prey items could suggest a generalist behavior of this predator, with several species that occasionally occurs in its diet. However, if prey are grouped into food categories, the importance of mesopelagic and benthopelagic fishes can be appreciated (54.41\% of \%IRI). The assessment of the hypothetical foraging rhythm of the Atlantic bluefin tuna highlighted that its feeding activity is concentrated on diel migrating fauna during night and on larger preys upon daylight. The predation on the highenergetic food as mesopelagic and bathypelagic fishes during the pre-spawning and the spawning period may
\end{abstract}

Communicated by Arne Malzahn.

P. Battaglia $(\bowtie) \cdot$ P. Consoli · V. Esposito · D. Malara ·

S. Musolino $\cdot$ C. Pedà · T. Romeo

Laboratory of Milazzo, ISPRA, Institute for Environmental

Protection and Research, via dei Mille 44, 98057 Milazzo,

ME, Italy

e-mail: pboceano@libero.it

F. Andaloro

ISPRA, Institute for Environmental Protection and Research,

c/o Residence Marbela, via Salvatore Puglisi 9,

90143 Palermo, Italy bring an energetic advantage in tuna metabolism and gonadal maturation

Keywords Diet - Scombridae - Thunnus thynnus . Feeding ecology $\cdot$ Mediterranean sea

\section{Introduction}

Thunnus thynnus L. 1758 (Scombridae) is a large migratory predator living in the pelagic ecosystems of the Atlantic Ocean and the Mediterranean Sea, including the Black Sea (Whitehead et al. 1984-1986). This species is worldwide considered a valuable fishery resource, and its management is a main issue for the international communities, social parts and scientists. The importance of the Atlantic bluefin tuna has been emphasized at international level since the 1966, during the Conference of Plenipotentiaries (Rio de Janeiro, Brazil), which established the International Commission for the Conservation of Atlantic Tunas (ICCAT) and adopted the Convention for the Conservation of Atlantic Tunas. From that moment on, several international institutions, commissions and conventions have focused their efforts on the conservation status of T. thynnus (i.e., GFCM of the FAO, Convention on Migratory Species of Wild Animals of Bonn in 1983, IUCN, CITES). In fact, from an ecological point of view, $T$. thynnus plays the significant role of top predator in the pelagic trophic web, regulating and controlling the ecosystem balance and prey biomass by a constant predation, assuring a positive control on biodiversity by contributing to maintain its natural level. As reported by several authors (Sinopoli et al. 2004; Sarà and Sarà 2007; Karakulak et al. 2009; Romeo et al. 2011), T. thynnus feeds on a broad spectrum of prey and has been described as an opportunistic feeder. Moreover, the Atlantic bluefin tuna is a long-lived 
fish (Santamaria et al. 2009), and its feeding habits are influenced by ontogenetic changes (Sarà and Sarà 2007), with a wide range of prey including zooplankton, fishes, cephalopods and crustaceans. So a significant number of links with other marine species was reported in the Atlantic bluefin tuna's feeding ecology, and the multiplicity of these connections and interactions adds complexity to the hard issue of tuna stock management. Therefore, to better manage this resource, as suggested by the principles of the Ecosystem Approach to Fisheries (EAF) (Garcia et al. 2003), is strongly recommended an improvement of the understanding of ecosystem structure and functioning (i.e., trophic web and predator-prey relationships), including increased knowledge of the component species and their role in the ecosystem. In the last decade, several efforts have been made by the scientific community to investigate the biology and ecology of $T$. thynnus, and new studies employing innovative techniques (i.e., archival tags, natural markers as genetics or otolith chemistry) shed light on tuna migration, trans-oceanic movements and the utilization of main spawning grounds and foraging areas (Rooker et al. 2003, 2006, 2007; Karakulak et al. 2004; Block et al. 2005; De Metrio et al. 2005). In the Mediterranean Sea, young-of-the-year tuna diet was investigated using stomach content analysis (Sinopoli et al. 2004), while feeding behavior of adult fishes was studied both by carbon- and nitrogen-stable isotopes and stomach analyses (Sarà and Sarà 2007; Karakulak et al. 2009). However, a significant lack on the Atlantic bluefin tuna feeding habits is still palpable, and it is mainly due to the difficult in monitoring the diet of this species during the whole year because of their migratory behavior. For this reason, the aim of this paper is to contribute to extend the knowledge on the trophic behavior of the Atlantic bluefin tuna in the Strait of Messina (central Mediterranean Sea). This location is closely joined to the primary spawning and recruitment areas of the Atlantic bluefin tuna in the southern Italy around Sicily (Sella 1924, 1929; Sanzo 1932; Piccinetti and Piccinetti Manfrin 1970; Tsuji et al. 1997; Nishida et al. 1998; La Mesa et al. 2005), and it is well known to be an important upwelling area of the central Mediterranean (Mazzarelli 1909; Vercelli 1925; Bignami and Salusti 1990). In particular, the study on the diet composition was carried out by stomach content analyses, and information was given on the feeding strategy of T. thynnus. An assessment of the daily foraging rhythm of the Atlantic bluefin tuna in the Strait of Messina was also given.

\section{Materials and methods}

Overall, 123 stomachs of $T$. thynnus were collected during spring seasons of 2010 and 2011 in the Strait of Messina (central Mediterranean Sea) (Fig. 1). Samples were

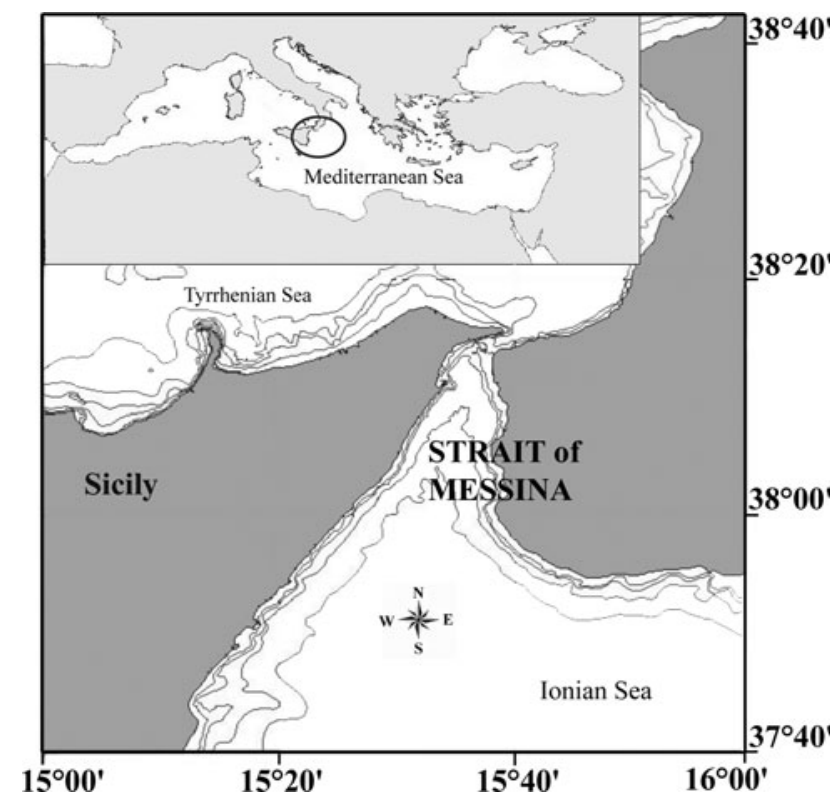

Fig. 1 Location of the study area in the Strait of Messina

obtained from hand line fishery, carried out during daylight by small crafts in the study area already described by several Authors (Berdar et al. 1995; Potoschi and Sturiale 1996; Di Natale et al. 2005). At landings, the fork length (FL in $\mathrm{cm}$ ), the gilled and gutted weight (GWT) of each individual and the hour of the catch were recorded, while the stomach was removed and frozen at $-18{ }^{\circ} \mathrm{C}$. Fishermen were asked about the bait used during fishing operation, in order to recognize this one from real prey and exclude it from analysis.

Stomachs were dissected in laboratory, and their content was observed using stereomicroscope. Qualitative analysis allowed us to identify entire or partially digested prey to the lowest possible taxa, following taxonomic features reported by Whitehead et al. (Whitehead et al. 1984-1986) for fishes, Roper et al. (1984), Jereb and Roper (2005, 2010), Young et al. (2010) for cephalopods, Falciai and Minervini (1992), Riedl (1991) for crustaceans and invertebrates. When prey were found in an advanced status of digestion, the identification of otoliths and cephalopod lower beaks was a powerful mean in their classification, which was performed using taxonomic keys (Clarke 1986; Tuset et al. 2008), as well as a reference to ISPRA collections (Pedà et al. 2009; Battaglia et al. 2010).

The identified preys were counted and weighed; entire specimens were preserved in $70 \%$ ethanol, while beaks were immersed in a mixture of ethanol, glycerine and water.

Quantitative analysis was performed only on fresh prey found in the stomach content, while accumulated prey items were excluded. In fact, hard parts are resistant to digestion (i.e. cephalopod beaks and otoliths) and may 
cumulate in the stomachs over more meals, leading to an overestimation of the importance of prey they belong to. Then, as hypothesized by Santos et al. (2001), only prey bearing fleshy remains were supposed to have been recently eaten by the predator.

The importance of the different prey items to the diet of $T$. thynnus was assessed by calculating the following dietary indexes: abundance percentage $(\% N=$ number of individuals of prey $i$ total number of prey $\times 100)$ and weight percentage $(\% \mathrm{~W}=$ weight of prey $i /$ total weight of all prey $\times 100)$, frequency of occurrence $(\% F=$ number of stomachs containing prey $i /$ total number of stomachs containing prey $\times 100)$. These values were combined to calculate the IRI for each prey and the \%IRI was also estimated (Pinkas et al. 1971; Hyslop 1980; Hacunda 1981): $\quad I R I=(\% N+\% W)(\% F)$ and $\% I R I_{i}=\left(I R I_{i} /\right.$ $\left.\sum I R I\right) \times 100$.

The feeding behavior of $T$. thynnus was assessed by a Costello graphical method (Costello 1990) modified by Amundsen et al. (1996), plotting the prey-specific abundance against the frequency of occurrence in a twodimensional graph. The prey-specific abundance is summarized as follows:

$P_{i}=\left(\sum S_{i} / \sum S_{t i}\right) \times 100$

where $P_{i}$ is the prey-specific abundance of prey $i, S_{i}$ is the total abundance (as weight or number) of prey $i$, and $S_{t i}$ is the total stomach content in only those specimens with prey $i$ in their stomachs. According to Amundsen et al. (1996), information on prey importance, feeding strategy and niche width contribution can be inferred through the position of prey types in the two-dimensional plot.

In order to assess the hypothetical daily foraging rhythm of the Atlantic bluefin tuna, preyed items (and, specifically, the predominant species detected in the stomach content) were separated into four subgroups according to the digestion stage: (1) Entire prey; (2) Intermediate 1 (low degree of digestion); (3) Intermediate 2 (high degree of digestion, but fleshy remains are present); (4) Accumulated prey (hard remains, that is, cephalopod beaks, fish otoliths). Following Pusineri et al. (2005), the digestion stage was then compared with the hour of catch and was estimated the hour of feeding, taking into account that tunas are able to totally digest a fish of medium size in about $24 \mathrm{~h}$ (transit time assessed from the examination of stomach contents), as stated by Aloncle and Delaporte (1973). Moreover, as cephalopod beaks are resistant to digestion (Santos et al. 2001), beaks without fresh remains were considered belonging to cephalopods caught prior to the day of sampling, whereas beaks still in the buccal mass were related to specimens eaten during early evening, in a time less than $24 \mathrm{~h}$ of tuna catch (Pusineri et al. 2005).

\section{Results}

Tuna ranged from 115 to $222 \mathrm{~cm}$ FL (mean FL $=154.0 \pm$ $27.4 \mathrm{~cm}$ ) and from 26 to $172 \mathrm{~kg}$ of gilled and gutted weight (mean GWT $=56.7 \pm 33.2 \mathrm{~kg}$ ). The size distribution of all specimens is given in Fig. 2. Over 123 stomachs analyzed, only 11 resulted empty $(8.9 \%)$, while in the remaining $112(91.1 \%)$ one prey at least was found.

Overall 91 taxa of prey items were identified in the stomach content of the Atlantic bluefin tuna, mainly belonging to Teleostea (54), Cephalopoda (20) and Crustacea (13). However, some of them were excluded from the quantitative analysis since only hard remains were found in the stomachs: the cephalopod Tremoctopus violaceus Delle Chiaje 1830 and the teleosts Gymnammodytes cicerelus (Rafinesque, 1810), Mora moro (Risso 1810), Coelorinchus coelorhinchus (Risso 1810), Hymenocephalus italicus Giglioli 1884.

Diet composition of $T$. thynnus and dietary indexes (abundance percentage, weight percentage, frequency of occurrence, IRI and \%IRI) calculated for each prey item are reported in Table 1. The percentage of IRI shows the highest values for the myctophid teleost Hygophum benoiti (Cocco 1838) $(\% I R I=22.854)$ and the stomiid Chauliodus sloani Bloch \& Schneider, $1810(\% I R I=15.124)$, followed by the oegopsid squid Illex coindetii (Vérany 1839) $(\% I R I=14.316)$ and the lanternfish Ceratoscopelus maderensis (Lowe 1839) (\%IRI = 11.680). However, an elevated contribute in terms of number of prey $(\% N)$ was given by the sergestid shrimps Sergestes corniculum (Kroyer 1855) $(\% N=19.439)$ and Sergestes robustus (Smith 1882) $(\% N=16.552)$, while the carangid Trachurus picturatus (Bowdich 1825$) \quad(\% W=11.167)$ and Anguilla anguilla (Linnaeus 1758) $(\% W=9.558)$ together with $C$. sloani $(\% W=13.711)$ and $I$. coindetii $(\% W=$ $11.200)$ represented $45 \%$ of prey biomass. Furthermore, the most frequently consumed prey were myctophids, $H$.

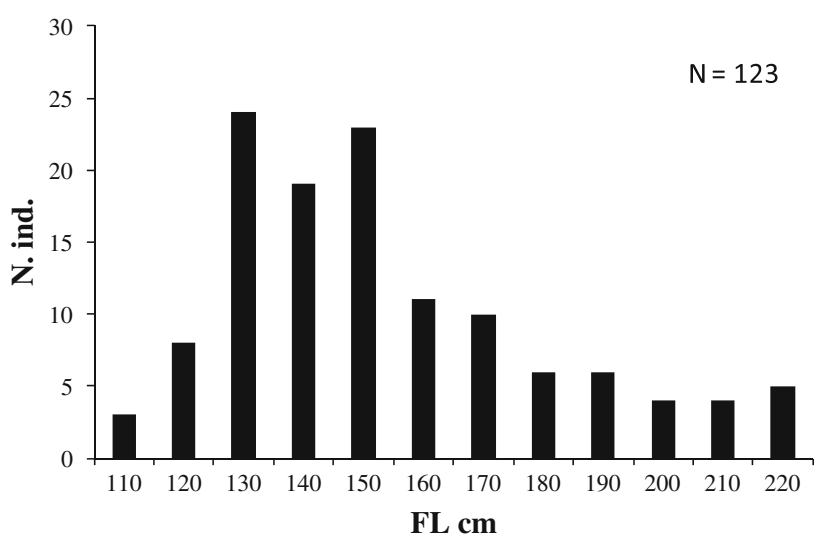

Fig. 2 Fork length frequency distribution of Atlantic bluefin tuna specimens sampled in the Strait of Messina 
Table 1 Diet composition of $T$. thynnus and dietary indexes calculated for each prey item: abundance percentage $(\% N)$, weight percentage $(\% W)$, frequency of occurrence $(\% F)$, index of relative abundance (IRI), IRI percentage (\%IRI)

\begin{tabular}{|c|c|c|c|c|c|c|c|}
\hline Class and order & Family & Species & $\% N$ & $\% W$ & $\% F$ & $\operatorname{IRI}$ & $\% I R I$ \\
\hline \multicolumn{8}{|l|}{ Hydrozoa } \\
\hline Siphonophora & Diphyidae & Diphyidae unid. & 0.503 & 0.002 & 8.929 & 4.514 & 0.135 \\
\hline \multicolumn{8}{|l|}{ Crustacea } \\
\hline \multirow[t]{4}{*}{ Amphipoda } & Phronimidae & Phronima sedentaria (Forskal, 1775) & 0.344 & 0.009 & 3.571 & 1.263 & 0.038 \\
\hline & Phrosinidae & Phrosina semilunata (Risso, 1882) & 0.212 & 0.009 & 4.464 & 0.984 & 0.030 \\
\hline & Platyscelidae & Platyscelus ovoides (Risso, 1816) & 0.053 & 0.002 & 1.786 & 0.098 & 0.003 \\
\hline & Lycaeidae & Lycaeidae unid. & 0.424 & 0.000 & 0.893 & 0.379 & 0.011 \\
\hline Copepoda & & Copepoda unid. & 0.026 & 0.000 & 0.893 & 0.024 & 0.001 \\
\hline \multirow[t]{9}{*}{ Decapoda } & Aristeidae & Aristaeomorpha foliacea (Risso, 1827) & 0.026 & 0.144 & 0.893 & 0.152 & 0.005 \\
\hline & Benthesicymidae & Gennadas elegans (Smith, 1882) & 0.026 & 0.002 & 0.893 & 0.025 & 0.001 \\
\hline & Sergestidae & Sergestes corniculum (Kroyer, 1855) & 19.439 & 1.270 & 15.179 & 314.331 & 9.433 \\
\hline & & Sergestes robustus (Smith, 1882) & 16.552 & 1.671 & 16.964 & 309.138 & 9.277 \\
\hline & Oplophoridae & Acanthephyra purpurea (Milne-Edwards, 1881) & 0.026 & 0.003 & 0.893 & 0.027 & 0.001 \\
\hline & Pasiphaeidae & Pasiphaea multidentata (Esmark, 1866) & 0.662 & 0.071 & 5.357 & 3.927 & 0.118 \\
\hline & & Pasiphaea sivado (Risso, 1816) & 0.079 & 0.012 & 1.786 & 0.164 & 0.005 \\
\hline & & Pasiphaea sp. & 0.132 & 0.005 & 1.786 & 0.246 & 0.007 \\
\hline & & Crustacea unid. & 0.026 & 0.000 & 0.893 & 0.024 & 0.001 \\
\hline \multicolumn{8}{|l|}{ Cephalopoda } \\
\hline Sepiolida & Sepiolidae & Heteroteuthis dispar (Rüppell, 1844) & 0.477 & 0.161 & 7.143 & 4.555 & 0.137 \\
\hline \multirow[t]{16}{*}{ Teuthida } & Brachioteuthidae & Brachioteuthis riisei (Steenstrup, 1882) & 0.026 & 0.013 & 0.893 & 0.036 & 0.001 \\
\hline & Cranchiidae & Galiteuthis armata (Joubin, 1898) & 0.026 & 0.006 & 0.893 & 0.029 & 0.001 \\
\hline & Thysanoteuthidae & Thysanoteuthis rhombus (Troschel, 1857) & 0.026 & 5.651 & 0.893 & 5.069 & 0.152 \\
\hline & Enoploteuthidae & Abralia veranyi (Férussac, 1835) & 0.238 & 0.149 & 3.571 & 1.384 & 0.042 \\
\hline & & Abraliopsis morisii (Vérany, 1839). & 0.106 & 0.011 & 1.786 & 0.210 & 0.006 \\
\hline & Pyroteuthidae & Pyroteuthis margaritifera (Ruppell, 1844) & 0.053 & 0.006 & 0.893 & 0.053 & 0.002 \\
\hline & Onycoteuthidae & Onychoteuthis banksii (Leach, 1817) & 0.556 & 0.298 & 7.143 & 6.102 & 0.183 \\
\hline & & Ancistroteuthis lichtensteinii (Férussac, 1835) & 0.053 & 0.030 & 1.786 & 0.148 & 0.004 \\
\hline & Ommastrephidae & Ommastrephes bartramii (Lesueur, 1821) & 1.033 & 1.723 & 7.143 & 19.686 & 0.591 \\
\hline & & Illex coindetii (Vérany, 1839) & 2.860 & 11.200 & 33.929 & 477.055 & 14.316 \\
\hline & & Todarodes sagittatus (Lamarck, 1798) & 0.477 & 2.305 & 7.143 & 19.867 & 0.596 \\
\hline & Histioteuthidae & Histioteuthis bonnellii (Férussac, 1835) & 0.821 & 2.166 & 8.929 & 26.669 & 0.800 \\
\hline & & Histioteuthis reversa (Verrill, 1880) & 0.053 & 0.606 & 1.786 & 1.177 & 0.035 \\
\hline & Octopoteuthidae & Octopoteuthis sicula Rüppell, 1844 & 0.026 & 0.015 & 0.893 & 0.037 & 0.001 \\
\hline & Chiroteuthidae & Chiroteuthis veranyi (Férussac, 1835) & 0.079 & 0.458 & 2.679 & 1.439 & 0.043 \\
\hline & & Teuthida unid. & 0.026 & 0.002 & 0.893 & 0.026 & 0.001 \\
\hline Myopsida & Loliginidae & Loligo vulgaris Lamarck, 1798 & 0.026 & 0.007 & 0.893 & 0.030 & 0.001 \\
\hline \multirow[t]{2}{*}{ Octopoda } & Argonautidae & Argonauta argo Linnaeus, 1758 & 0.212 & 0.272 & 5.357 & 2.590 & 0.078 \\
\hline & & Cephalopoda unid. & 0.159 & 0.024 & 5.357 & 0.979 & 0.029 \\
\hline \multicolumn{8}{|l|}{ Tunicata } \\
\hline \multirow[t]{2}{*}{ Salpida } & & Salpida ind & 0.583 & 0.043 & 1.786 & 1.117 & 0.034 \\
\hline & Pyrosomatidae & Pyrosoma atlanticum Péron, 1804 & 0.132 & 0.033 & 0.893 & 0.147 & 0.004 \\
\hline Doliolida & Doliolidae & Doliolum sp. & 1.033 & 0.067 & 5.357 & 5.890 & 0.177 \\
\hline \multicolumn{8}{|l|}{ Teleostea } \\
\hline \multirow[t]{5}{*}{ Aulopiformes } & Paralepididae & Paralepis coregonoides Risso, 1820 & 0.053 & 0.005 & 1.786 & 0.104 & 0.003 \\
\hline & & Paralepis speciosa Bellotti, 1878 & 0.026 & 0.010 & 0.893 & 0.032 & 0.001 \\
\hline & & Sudis hyalina Rafinesque, 1810 & 0.079 & 0.029 & 2.679 & 0.290 & 0.009 \\
\hline & & Arctozenus risso (Bonaparte, 1840) & 0.079 & 0.022 & 2.679 & 0.272 & 0.008 \\
\hline & & Paralepididae unid. & 0.026 & 0.015 & 0.893 & 0.037 & 0.001 \\
\hline
\end{tabular}


Table 1 continued

\begin{tabular}{|c|c|c|c|c|c|c|c|}
\hline Class and order & Family & Species & $\% N$ & $\% W$ & $\% F$ & IRI & $\% I R I$ \\
\hline Clupeiformes & Clupeidae & Sardinella aurita (Valenciennes, 1847) & 0.106 & 2.476 & 2.679 & 6.917 & 0.208 \\
\hline \multirow[t]{17}{*}{ Perciformes } & \multirow[t]{5}{*}{ Carangidae } & Caranx crysos (Geoffroy Saint Hilaire, 1809) & 0.026 & 3.113 & 0.893 & 2.803 & 0.084 \\
\hline & & Trachurus picturatus (Bowdich, 1825) & 0.318 & 11.167 & 7.143 & 82.033 & 2.462 \\
\hline & & Trachurus mediterraneus (Steindachner, 1868) & 0.053 & 0.028 & 1.786 & 0.145 & 0.004 \\
\hline & & Trachurus sp. & 0.079 & 0.131 & 0.893 & 0.188 & 0.006 \\
\hline & & Carangidae unid. & 0.026 & 1.161 & 0.893 & 1.061 & 0.032 \\
\hline & Centracanthidae & Spicara maena (Linnaeus, 1758) & 0.053 & 0.261 & 1.786 & 0.560 & 0.017 \\
\hline & \multirow[t]{2}{*}{ Centrolophidae } & Centrolophus niger (Gmelin, 1788) & 0.026 & 0.020 & 0.893 & 0.041 & 0.001 \\
\hline & & Schedophilus medusophagus (Cocco, 1839) & 0.026 & 0.027 & 0.893 & 0.048 & 0.001 \\
\hline & Nomeidae & Cubiceps gracilis (Lowe, 1843) & 0.026 & 0.024 & 0.893 & 0.045 & 0.001 \\
\hline & \multirow[t]{3}{*}{ Scombridae } & Auxis rochei (Risso, 1810) & 0.026 & 4.320 & 0.893 & 3.881 & 0.116 \\
\hline & & Sarda sarda (Bloch, 1793) & 0.026 & 4.213 & 0.893 & 3.786 & 0.114 \\
\hline & & Scomber japonicus (Gmelin, 1789) & 0.026 & 0.662 & 0.893 & 0.614 & 0.018 \\
\hline & \multirow[t]{4}{*}{ Sparidae } & Boops boops (Linnaeus, 1758) & 0.344 & 3.934 & 5.357 & 22.918 & 0.688 \\
\hline & & Dentex gibbosus (Rafinesque, 1810) & 0.026 & 0.629 & 0.893 & 0.585 & 0.018 \\
\hline & & Sarpa Salpa (Linnaeus, 1758) & 0.026 & 1.393 & 0.893 & 1.268 & 0.038 \\
\hline & & Sparidae unid. & 0.132 & 0.074 & 3.571 & 0.736 & 0.022 \\
\hline & Trichiuridae & Lepidopus caudatus (Euphrasen, 1788) & 0.106 & 1.154 & 2.679 & 3.376 & 0.101 \\
\hline \multirow[t]{2}{*}{ Beloniformes } & Belonidae & Belone belone gracilis (Linnaeus, 1761) & 0.026 & 0.005 & 0.893 & 0.028 & 0.001 \\
\hline & Scomberesocidae & Scomberesox saurus (Walbaum, 1792) & 0.265 & 0.134 & 3.571 & 1.426 & 0.043 \\
\hline \multirow[t]{8}{*}{ Stomiiformes } & Gonostomatidae & Gonostoma denudatum Rafinesque, 1810 & 0.053 & 0.068 & 1.786 & 0.216 & 0.006 \\
\hline & \multirow[t]{3}{*}{ Phosichthyidae } & Ichthyococcus ovatus (Cocco, 1838) & 0.106 & 0.011 & 0.893 & 0.105 & 0.003 \\
\hline & & Vinciguerria attenuata (Сосco, 1838) & 0.715 & 0.022 & 7.143 & 5.263 & 0.158 \\
\hline & & Vinciguerria poweriae (Сocco, 1838) & 0.079 & 0.027 & 1.786 & 0.190 & 0.006 \\
\hline & \multirow[t]{2}{*}{ Sternoptychidae } & Argyropelecus hemygimnus Сocco, 1829 & 0.079 & 0.023 & 1.786 & 0.182 & 0.005 \\
\hline & & Maurolicus muelleri Gmelin, 1789 & 0.715 & 0.224 & 14.286 & 13.411 & 0.402 \\
\hline & \multirow[t]{2}{*}{ Stomiidae } & Chauliodus sloani Bloch \& Schneider, 1810 & 10.832 & 13.711 & 20.536 & 504.003 & 15.124 \\
\hline & & Stomias boa boa (Risso, 1810) & 0.079 & 0.032 & 2.679 & 0.298 & 0.009 \\
\hline \multirow[t]{11}{*}{ Myctophiformes } & \multirow[t]{11}{*}{ Myctophidae } & Benthosema glaciale (Reinhardt, 1837) & 1.377 & 0.344 & 7.143 & 12.296 & 0.369 \\
\hline & & Ceratoscopelus maderensis (Lowe, 1839) & 8.316 & 2.317 & 36.607 & 389.215 & 11.680 \\
\hline & & Diaphus holti Tåning, 1918 & 1.457 & 0.265 & 12.500 & 21.525 & 0.646 \\
\hline & & Electrona risso Cocco, 1829 & 1.192 & 0.292 & 6.250 & 9.276 & 0.278 \\
\hline & & Hygophum benoiti (Cocco, 1838) & 15.810 & 4.994 & 36.607 & 761.597 & 22.854 \\
\hline & & Hygophum hygomii (Lütken, 1892) & 0.980 & 0.073 & 8.929 & 9.398 & 0.282 \\
\hline & & Lampanyctus crocodilus Risso, 1810 & 0.900 & 0.531 & 6.250 & 8.950 & 0.269 \\
\hline & & Lampanyctus pusillus (Johnson, 1890) & 0.265 & 0.026 & 3.571 & 1.039 & 0.031 \\
\hline & & Myctophum punctatum Rafinesque, 1810 & 3.708 & 1.272 & 25.893 & 128.946 & 3.869 \\
\hline & & Notoscopelus elongatus (Costa, 1844) & 1.536 & 0.237 & 9.821 & 17.415 & 0.523 \\
\hline & & Symbolophorus veranyi (Moreau, 1888) & 0.026 & 0.031 & 0.893 & 0.051 & 0.002 \\
\hline Zeiformes & Caproidae & Capros aper (Linnaeus, 1758) & 0.344 & 1.870 & 1.786 & 3.955 & 0.119 \\
\hline \multirow[t]{2}{*}{ Gadiformes } & Gadidae & Micromesistius poutassou (Risso, 1827) & 0.053 & 0.253 & 0.893 & 0.273 & 0.008 \\
\hline & Merluccidae & Merluccius merluccius (Linnaeus, 1758) & 0.026 & 0.122 & 0.893 & 0.132 & 0.004 \\
\hline Anguilliformes & Anguillidae & Anguilla anguilla (Linnaeus, 1758) & 0.662 & 9.558 & 8.929 & 91.247 & 2.738 \\
\hline \multirow[t]{3}{*}{ Osmeiformes } & \multirow[t]{3}{*}{ Microstomatidae } & Microstoma microstoma (Risso, 1810) & 0.106 & 0.126 & 2.679 & 0.620 & 0.019 \\
\hline & & Nansenia oblita (Facciolà, 1887) & 0.053 & 0.011 & 1.786 & 0.114 & 0.003 \\
\hline & & Teleostea unid. & 0.900 & 0.106 & 9.821 & 9.880 & 0.296 \\
\hline
\end{tabular}

Unid. unidentified 


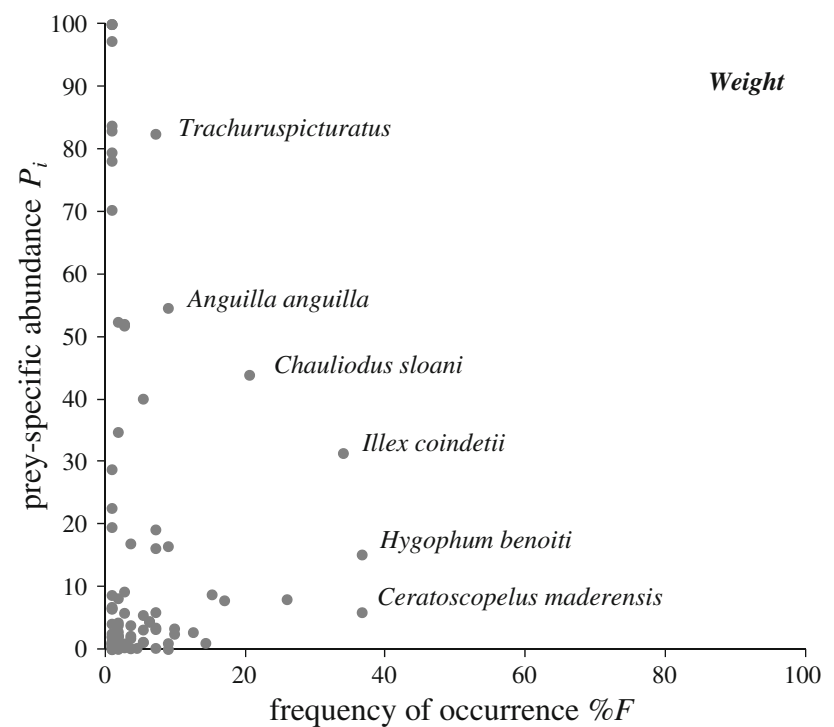

Fig. 3 Relationship between prey-specific abundance $\left(P_{i}\right)$, expressed as weight, and frequency of occurrence $(\% F)$ of prey items in the diet of T. thynnus, collected in the Strait of Messina

benoiti and $C$. maderensis, that recorded the same value of $\% F=36.607$.

The feeding pattern of the Atlantic bluefin tuna is graphically represented in Figs. 3 and 4, where the frequency of occurrence $(\% F)$ is plotted against prey-specific abundance $\left(P_{i}\right)$, expressed, respectively, as weight and number. In Fig. 5, the explanatory Costello diagram (modified from Amundsen et al. 1996) for the interpretation on feeding strategy is reported. Most of the food categories are located in the lower left corner of the diagrams or close to the vertical axis, in a region of low prey importance. Then, all these species are rare or unimportant prey, being consumed by a low percentage of predators, as indicated by the low values of frequency of occurrence. However, some prey items resulted most frequently eaten by $T$. thynnus (H. benoiti, C. maderensis, I. coindetii, C. sloani).

Looking at the Costello diagram (modified from Amundsen et al. 1996), no single species can be defined as dominant in the diet of the Atlantic bluefin tuna in the study area; in spite of this, grouping prey into food categories (Fig. 6), the importance of migrating mesopelagic and benthopelagic fishes are well evident by the value of \%IRI (54.41\%), followed by oegopsid squids $(\% I R I=18.95 \%)$. The pelagic shrimps (mainly Sergestidae) were largely preyed by the Atlantic bluefin tuna, but their contribution in terms of biomass $(\% W)$ resulted low. As regards eels and epipelagic fishes, they were both represented in most cases by few medium-large prey.

The digestion status of prey and the hypothetical foraging rhythm of the Atlantic bluefin tuna in the Strait of Messina are shown in Fig. 7. The Atlantic bluefin tuna

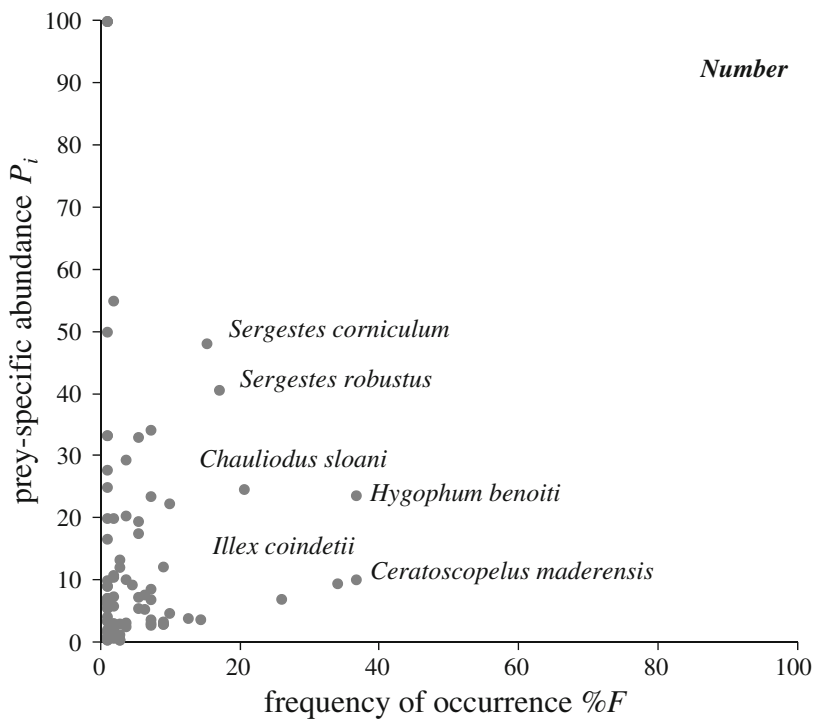

Fig. 4 Relationship between prey-specific abundance $\left(P_{i}\right)$, expressed as number of prey, and frequency of occurrence $(\% F)$ of prey items in the diet of T. thynnus, collected in the Strait of Messina

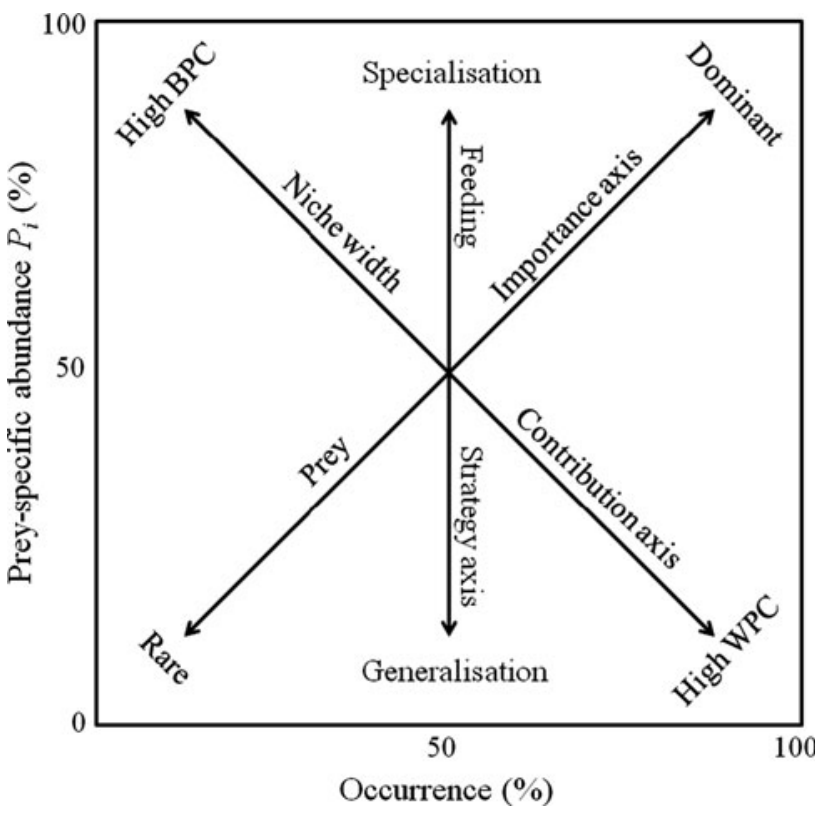

Fig. 5 The explanatory Costello diagram (modified from Amundsen et al. 1996) and its interpretation on feeding strategy. (BPC = between-phenotype component, $W P C=$ within-phenotype component)

feeding activity during night was concentrated on diel migrating fauna (Myctophidae, Stomiidae, Paralepididae, crustaceans and cephalopods). By the analysis of digestion status of prey, the predation on crustaceans and cephalopods was carried out also during daylight, while carangids and eels were usually eaten during day. However, an occasional feeding on eels during night was also recorded. 


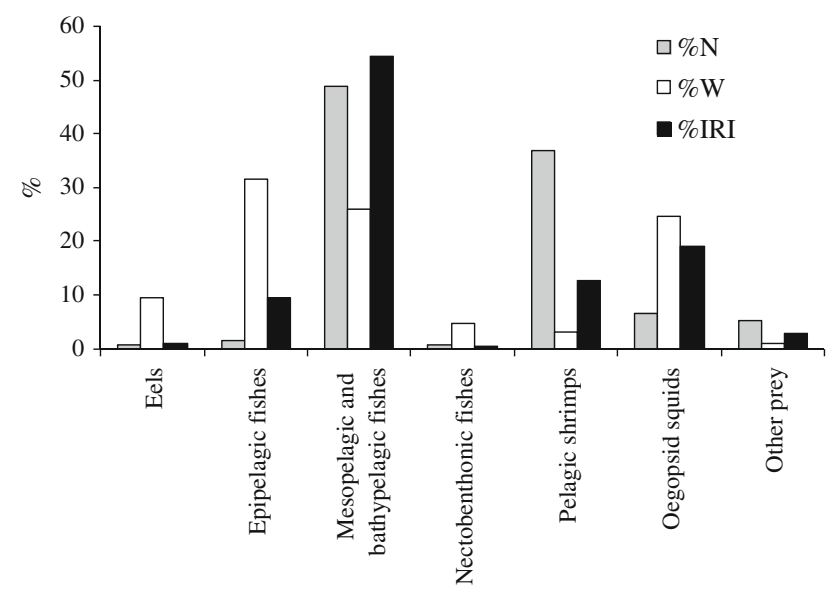

Fig. 6 Abundance $(\% N)$, weight $(\% W)$ and IRI $(\% I R I)$ percentage for Atlantic bluefin tuna food items grouped into 7 categories: eels, epipelagic fishes, mesopelagic and bathypelagic fishes, nectobenthonic fishes, pelagic shrimps, oegopsid squids, other prey

Further considerations on the foraging rhythm of $T$. thynnus are given in the discussion.

\section{Discussion}

The analysis of feeding habits of the Atlantic bluefin tuna in the central Mediterranean (Strait of Messina) showed that teleosts represent the main fraction of food during spring season, even if cephalopods and crustaceans can be considered other important source of energy, while remaining systematic taxa (Hydrozoa and Tunicata) have a negligible impact on the diet. This supports the results of other Authors in Mediterranean (Genovese 1960; Genovese and Alonzo 1961; Karakulak et al. 2009) and Atlantic Ocean (Eggleston and Bochenek 1990; Chase 2002; Logan et al. 2011), which described adult Atlantic bluefin tuna as primarily piscivorus predator. On the contrary, the diet of young-of-the-year $T$. thynnus seems to vary depending on area and available prey, relying mainly on cephalopods and fishes in the northern Tyrrhenian Sea (Piccinetti and Piccinetti Manfrin 1970), crustaceans and fishes in the Ligurian Sea (Orsi Relini et al. 1998), whereas fishes, followed by crustaceans and cephalopods, were the most abundant prey items in the southern Tyrrhenian and in the western Mediterranean (Sanz Brau 1990; Sinopoli et al. 2004).

According with similar studies (Chase 2002; Sinopoli et al. 2004; Karakulak et al. 2009), the Atlantic bluefin tuna shows a broad spectrum of prey items (91); this could underline a generalist behavior of this predator, with several species that occasionally occurs in its diet, as also indicated by the application of Costello graphical method modified by Amundsen et al. (1996). However, if prey are grouped into food categories, the importance of mesopelagic and benthopelagic fishes can be appreciated, reaching the $54.41 \%$ of \%IRI. Schoolings of vertically migrating Myctophidae, Stomiidae, Paralepididae, Sternoptychidae, Gonostomatidae, Microstomatidae and Phosichthydae are in fact abundant in the area, being concentrated by currents and upwelling phenomena (Mazzarelli 1909; Genovese et al. 1971) and constituting easily available food for the Atlantic bluefin tuna and other predators (Guglielmo et al. 1995). The diel vertical migration of pelagic organisms offers also to $T$. thynnus the possibility of collecting planktonic crustaceans (mainly Sergestidae and Pasiphaeidae) and squids (in particular Ommastrephidae). On the other hand, if the predation on mesopelagic fauna is facilitated by the rising of these species toward upper water layers during their nocturnal movements, it is also true that the Atlantic bluefin tuna is also able to perform vertical excursion to hunt in deeper waters (i.e., $>600 \mathrm{~m}$, as reported by Block et al. 2001). The evidence of this behavior in the study area can be ascribed to the finding of deep-sea demersal species in the stomachs, such as the crustacean Aristaeomorpha foliacea (Risso 1827) and the teleosts Capros aper (Linnaeus 1758), M. moro, $C$. coelorhinchus and $H$. italicus as well as deep-sea squids during daytime. The ingestion of demersal preys in deep or coastal waters was also reported by other Authors (Genovese 1960; Genovese and Alonzo 1961; Chase 2002; Karakulak et al. 2009); then, it appears that the Atlantic bluefin tuna sporadically moves to the bottom to feed on benthic organisms.

By comparing the digestion status of prey with the hour of predator catch by fishermen, it was possible to assess the hypothetical foraging rhythm of the Atlantic bluefin tuna in the Strait of Messina. The analysis of these data highlights a possible daily pattern in tuna diet, with a feeding activity concentrated on diel migrating fauna during night and the predation on larger preys upon daylight. Crustaceans were always found at a low stage of digestion as entire prey or fresh remains (digestion status: intermediate 1), and they were likely preyed from some hours before sunrise to daylight, although the predation on vertically migrating crustaceans also during early night cannot be excluded. In fact, the Atlantic bluefin tunas were sampled during daytime and these small-sized species are expected to be assimilated in few hours (Pusineri et al. 2005); for this reason, potential small crustacean prey eaten during early nighttime were not detected. Paralepidids were found at all digestion stages in the stomachs, but highly or fully digested individuals were mainly recorded in predators caught during the afternoon, indicating that they were preyed during night and early morning. As Paralepididae, also Myctophidae and Stomiidae were eaten during night feeding activity and sometimes at first hours of daylight. However, accumulated otoliths were detected mainly for 
Fig. 7 The hypothetical foraging rhythm of the Atlantic bluefin tuna during spring season in the Strait of Messina, as derived by comparison of the digestion states of main prey in the stomachs

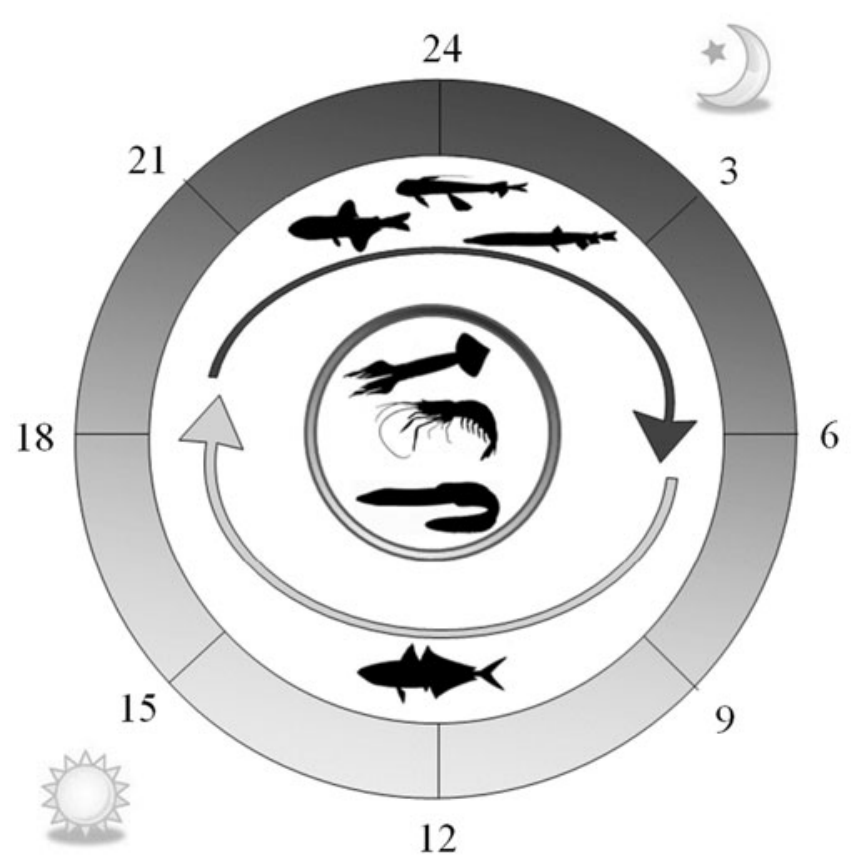

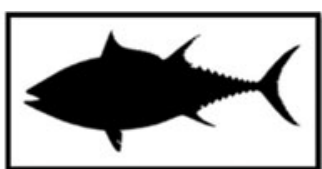

Bluefin tuna foraging rhythm

PREYITEMS
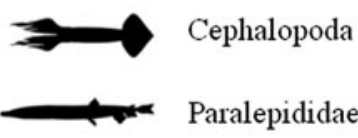

6

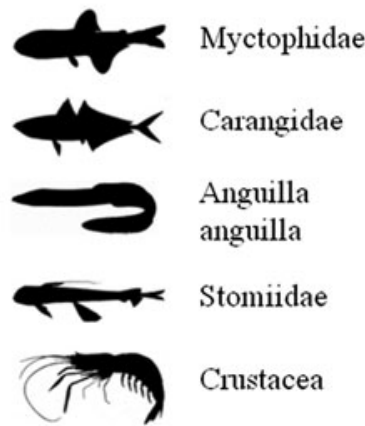

DIGESTION STATUS

$\square$ Accumulated prey

$\square$ Intermediate 2

- Intermediate 1

$\square$ Entire prey myctophid species, since sagittae of stomiid fishes are very small and they can be dissolved in few time. Together vertically migrating mesopelagic fishes, cephalopods were prey usually ingested during night as demonstrated by the large number of buccal masses found in the stomachs. Fully digested beaks were instead considered belonging to prey eaten at least $24 \mathrm{~h}$ prior to the sampling, because of their resistance to digestive processes (Santos et al. 2001). Nevertheless, entire cephalopod prey were recorded also in fishes caught during afternoon and late morning; hence, the predation on cephalopods is also stretched over all daytime. Large prey as carangids and eels were usually consumed during day, since they were mostly found as entire prey, but there was evidence of occasional feeding on eels also during night. This tuna feeding behavior was well known by old fishermen in the study area; in fact in the past, during the night, they used to fish tunas by hand lines baited with specimens of $A$. anguilla (Berdar et al. 1995).

Analyzing the results of this research, several connections and similarities can be found with findings of Karakulak et al. (2009) on Atlantic bluefin tuna' specimens ranging from 98.5 to $294 \mathrm{~cm}$ FL in the eastern Mediterranean Sea. In fact, both studies highlighted the tendency of the Atlantic bluefin tuna to forage on mesopelagic fauna 
(in particular Myctophidae and Stomiidae) during spring season, recording the lanternfish $H$. benoiti as the most important food item. Also, Piccinetti and Piccinetti Manfrin (1970) observed a high frequency of predation on mesopelagic fishes in the Tyrrhenian sea, but they were mainly Paralepididae. The dominance of these prey in the Atlantic bluefin tuna diet was not reported in other studies that instead underlined an high percentage of epipelagic species among fish prey, such as Ammodytes spp., Clupea harengus, Scomber scombrus (Eggleston and Bochenek 1990; Chase 2002; Logan et al. 2011) in the Atlantic Ocean and Engraulidae (Orsi Relini et al. 1998), Clupeidae (Sinopoli et al. 2004) and Boops boops and Trachurus sp. (Genovese 1960; Genovese and Alonzo 1961) in the Mediterranean Sea. Nevertheless, a quite important rate of mesopelagic fishes (mainly Paralepididae) among secondary prey was also recorded by Orsi Relini et al. 1998.

Mesopelagic fishes have already been reported among main prey of several like-tuna fishes. For instance, Thunnus alalunga is known as predator relying on Paralepididae and Sternoptychidae in Atlantic (Aloncle and Delaporte 1973; Pusineri et al. 2005) and Paralepididae in Mediterranean waters (Consoli et al. 2008). The deep-dwelling bigeye tuna Thunnus obesus is particularly able to exploit the migrant micronektonic species as source of regular food, feeding on significant amount of myctophids (Moteki et al. 2001; Bertrand et al. 2002), sternoptychids (Koga 1958; Moteki et al. 2001), alepisaurids (Koga 1958), paralepidids (Moteki et al. 2001; Potier et al. 2004), gempylids (Moteki et al. 2001) and scopelarchids (Potier et al. 2004). Also, yellowfin tuna Thunnus albacares forages on mesopelagic fishes (Sternoptychidae), as reported by Moteki et al. (2001) in eastern Pacific Ocean; however, in other areas, this species is considered a predator hunting mainly in shallower layers (Bertrand et al. 2002).

The occurrence of the mesopelagic and bathypelagic fauna in $T$. thynnus diet in the study area can be related to the presence of upwelling currents in the Strait of Messina. The abundance of these food resources may be constitute an attractive for an opportunistic feeder as the Atlantic bluefin tuna, able to forage on micronekton patches and aggregations.

However, another possible hypothesis is that the predation on this food category during the pre-spawning and the spawning period may bring an energetic advantage in tuna metabolism. In evidence, mesopelagic fishes are reported to have higher lipid content (e.g., wax esters) than several other marine fish (Benson and Lee 1972; Saito and Murata 1998; Lea et al. 2002), representing an important energy source for marine predators (e.g., Phleger et al. 1997; Moteki et al. 2001; Bertrand et al. 2002; Lea et al. 2002). Further studies should be carried out to deepen this aspect.
Acknowledgments The authors are grateful to the fishermen who collaborated in this study and to Mr. F. Ponsù for his help in the sampling operations.

\section{References}

Aloncle H, Delaporte F (1973) Rythmes alimentaires et circadiens chez le germon Thunnus alalunga dans le Nord-Est atlantique. Science Naturelles, Paris VI, Paris, p 96

Amundsen PA, Gabler HM, Staldvik FJ (1996) A new approach to graphical analysis of feeding strategy from stomach contents data-modification of the Costello (1990) method. J Fish Biol 48: 607-614

Battaglia P, Malara M, Romeo T, Andaloro F (2010) Relationships between otolith size and fish size in some mesopelagic and bathypelagic species from the Mediterranean Sea (Strait of Messina, Italy). Sci Mar 74(3):605-612

Benson AA, Lee RF (1972) Wax esters: major marine metabolic energy sources. Biochem J 128(1):10

Berdar A, Mento G, Costa F, Ammendolia G, Panebianco A, Ioli V (1995) Riflessioni sulla pesca fra Scilla e Cariddi. In: Jason (ed), pp 190

Bertrand A, Bard FX, Joss E (2002) Tuna food habits related to the micronekton distribution in French Polynesia. Mar Biol 140: $1023-1037$

Bignami F, Salusti E (1990) Tidal currents and transient phenomena in the Straits of Messina. A review. In: Pratt L (ed) The physical oceanography of Sea Straits. Kluwer Academic, Boston, pp 95-124

Block BA, Dewar H, Blackwell SB, Williams TD, Prince ED, Farwell CJ, Boustany A, Teo SL, Seitz A, Walli A, Fudge D (2001) Migratory movements, depth preferences and thermal biology of Atlantic bluefin tuna. Science 293:1310-1314

Block BA, Teo SLH, Walli A, Boustany A, Stokesbury MJW, Farwell CJ, Weng KC, Dewar H, Williams TD (2005) Electronic tagging and population structure of Atlantic bluefin tuna. Nature 434: $1121-1127$

Chase BC (2002) Difference in diet of Atlantic bluefin tuna (Thunnus thynnus) at five seasonal feeding grounds on the New England continental shelf. Fish Bull 100:168-180

Clarke MR (1986) A handbook for the identification of cephalopods beaks. Clarendon Press, Oxford, p 273

Consoli P, Romeo T, Battaglia P, Castriota L, Esposito V, Andaloro F (2008) Feeding habits of the albacore tuna Thunnus alalunga (Perciformes, Scombridae) from central Mediterranean Sea. Mar Biol 155:113-120

Costello MJ (1990) Predator feeding strategy and prey importance: a new graphical analysis. J Fish Biol 36:261-263

De Metrio G, Arnold GP, de la Serna JM, Block BA, Megalofonou P, Lutcavage M, Oray I, Deflorio M (2005) Movements of bluefin tuna (Thunnus thynnus L.) tagged in the Mediterranean Sea with pop-up satellite tags. Collect Vol Sci Pap ICCAT 58:1337-1340

Di Natale A, Mangano A, Piccinetti C, Ciavaglia E, Celona A (2005) Bluefin tuna (Thunnus thynnus) line fisheries in the italian seas. Old and recent data. Collect Vol Sci Pap ICCAT 58:1285-1295

Eggleston DB, Bochenek EA (1990) Stomach contents and parasite infestation of school bluefin tuna Thunnus thynnus collected from the middle Atlantic Bight, Virginia. Fish Bull 88:389-395

Falciai L, Minervini R (1992) Guida dei crostacei decapodi d'Europa. In: Muzzio F (ed), pp 283

Garcia SM, Zerbi A, Aliaume C, Do Chi T, Lasserre G (2003) The ecosystem approach to fisheries. Issues, terminology, principles, institutional foundations, implementation and outlook. FAO Fish Tech Pap 443, Rome, FAO, pp 71 
Genovese S (1960) Sul regime alimentare di Thunnus thynnus (L.). Boll Pesca Piscic Idrobiol 15:177-189

Genovese S, Alonzo V (1961) Sul contenuto stomacale di tonni [Thunnus thynnus (L.)] catturati nello Stretto di Messina ed in alcune tonnare della Sicilia e della Calabria. Atti Soc Pelor 7:1-8

Genovese S, Berdar A, Guglielmo L (1971) Spiaggiamenti di fauna abissale nello Stretto di Messina. Atti Soc Pelor Sci 17:331-370

Guglielmo L, Marabello F, Vanucci S (1995) The role of the mesopelagic fishes in the pelagic food web of the Straits of Messina In: Guglielmo L, Manganaro A, De Domenico E (eds) The Straits of Messina ecosystem. Proceedings of the Symposium held in Messina, 4-6 April 1991, pp 223-246

Hacunda JS (1981) Trophic relationships among demersal fishes in a coastal area of the Gulf of Maine. Fish Bull 79:775-788

Hyslop EJ (1980) Stomach content analysis: a review of methods and their application. J Fish Biol 17:411-422

Jereb P, Roper CFE (2005) Cephalopods of the world. An annotated and illustrated catalogue of cephalopod species known to date, vol 1. Chambered nautiluses and sepioids (Nautilidae, Sepiidae, Sepiolidae, Sepiadariidae, Idiosepiidae and Spirulidae), No. 4, vol 1. FAO Species Catalogue for Fishery Purposes, Rome, FAO, p 262

Jereb P, Roper CFE (2010) Cephalopods of the world. An annotated and illustrated catalogue of cephalopod species known to date, vol 2. Myopsid and Oegopsid Squids, No. 4, vol. 2. FAO Species Catalogue for Fishery Purposes, Rome, FAO, p 630

Karakulak S, Oray I, Corriero A, Deflorio M, Santamaria N, Desantis S, De Metrio G (2004) Evidence of a spawning area for the bluefin tuna (Thunnus thynnus L.) in the eastern Mediterranean. J Appl Ichthyol 20:318-320

Karakulak FS, Salman A, Oray IK (2009) Diet composition of bluefin tuna (Thunnus thynnus L. 1758) in the Eastern Mediterranean Sea, Turkey. J Appl Ichthyol 25(6):757-761

Koga S (1958) On the difference of the stomach contents of tunas and black marlin in south equatorial Pacific Ocean. Bull Fac Fish Nagasaki Univ 7:21-30

La Mesa M, Sinopoli M, Andaloro F (2005) Age and growth rate of juvenile bluefin tuna Thunnus Thynnus from the Mediterranean Sea (Sicily, Italy). Sci Mar 69(2):241-249

Lea MA, Nichols PD, Wilson G (2002) Fatty acid composition of lipid-rich myctophids and mackerel icefish (Champsocephalus gunnari)-Southern Ocean food-web implications. Polar Biol $25: 843-854$

Logan JM, Rodriguez-Marin E, Goñi N, Barreiro S, Arrizabalaga H, Golet W, Lutcavage M (2011) Diet of young Atlantic bluefin tuna (Thunnus thynnus) in eastern and western Atlantic forage grounds. Mar Biol 158:73-85

Mazzarelli G (1909) Gli animali abissali e le correnti sottomarine dello Stretto di Messina. Riv Mens Pesca Idrobiol 11:177-218

Moteki M, Arai M, Tsuchiya K, Okamoto H (2001) Composition of piscine prey in the diet of large pelagic fish in the eastern tropical Pacific Ocean. Fish Sci 67:1063-1074

Nishida T, Tsuji S, Segawa K (1998) Spatial data analyses of Atlantic bluefin tuna larval surveys in the 1994 ICCAT BYP. ICCAT Col Vol Sci Pap 48:107-110

Orsi Relini L, Cima C, Palandri G, Relini M, Garibaldi F (1998) Alimentazione del tonno giovanile nell'ecosistema del largo del Mar Ligure. Biol Mar Medit 5:63-70

Pedà C, Malara D, Battaglia P, Perzia P, Andaloro F, Romeo T (2009) I cefalopodi nella dieta di grandi pelagici: identificazione dei becchi e costituzione di un archivio fotografico di riferimento. Biol Mar Medit 16(1):354-355

Phleger CF, Nichols PD, Virtue P (1997) The lipid, fatty acid and fatty alcohol composition of the myctophid fish Electrona antarctica: high levels of wax esters and food-chain implications. Antarctic Sci 9:258-265
Piccinetti C, Piccinetti Manfrin G (1970) Osservazioni sulla biologia dei primi stadi giovanili del tonno (Thunnus thynnus L.) Boll Pesca Piscic Idrobiol 25:223-247

Pinkas L, Oliphant MS, Iverson ILK (1971) Food habits of albacore, blue fin tuna, and bonito in California waters. Calif Dept Fish Game Fish Bull 152:105

Potier M, Marsac F, Lucas V, Sabatié R, Hallier JP, Ménard F (2004) Feeding partitioning among tuna taken in surface and mid-water layers: the case of yellowfin (Thunnus albacares) and bigeye (T. obesus) in the western tropical Indian Ocean. Western Indian Ocean J Mar Sci 3(1):51-62

Potoschi A, Sturiale P (1996) La pesca del tonno all'amo nello Stretto di Messina, nell'ultimo secolo. Biol Mar Medit 3(1):297-302

Pusineri C, Vasseur Y, Hassani S, Meynier L, Spitz J, Ridoux V (2005) Food and feeding ecology of juvenile albacore, Thunnus alalunga, off the Bay of Biscay: a case study. ICES J Mar Sci 62:116-122

Riedl R (1991) Flora e fauna del Mediterraneo. In: Muzio F (ed), pp 777

Romeo $\mathrm{T}$, Battaglia $\mathrm{P}$, Pedà $\mathrm{C}$, Perzia $\mathrm{P}$, Consoli $\mathrm{P}$, Esposito $\mathrm{V}$, Andaloro F (2011) Pelagic cephalopods of the central Mediterranean Sea determined by the analysis of the stomach content of large fish predators. Helgol Mar Res (in press)

Rooker JR, Secor DH, Zdanowicz VS, De Metrio G, Orsi Relini L (2003) Identification of Atlantic bluefin tuna (Thunnus thynnus) stocks from putative nurseries using otolith chemistry. Fish Oceanogr 12(2):75-84

Rooker JR, Secor DH, De Metrio G, Rodriquez-Marin E (2006) Evaluation of population structure and mixing rates of Atlantic bluefin tuna from chemical signatures in otoliths. Collect Vol Sci Pap ICCAT 59:813-818

Rooker JR, Alvarado Bremer JR, Block BA, Dewar H, De Metrio G, Kraus RT, Prince ED, Rodriquez-Marin E, Secor DH (2007) Life history and stock structure of Atlantic bluefin tuna (Thunnus thynnus). Rev Fish Sci 15(4):265-310

Roper CFE, Sweeney MJ, Nauen CE (1984) FAO species catalogue. Vol. 3. Cephalopods of the world. An annotated and illustrated catalogue of species of interest to fisheries. FAO Fish Synop 125(3): 277

Saito H, Murata M (1998) Origin of the monoene fats in the lipid of midwater fishes: relationship between the lipids of myctophids and those of their prey. Mar Ecol Prog Ser 168:21-33

Santamaria N, Bello G, Corriero A, Deflorio M, Vassallo-Agius R, Bok T, De Metrio G (2009) Age and growth of Atlantic bluefin tuna, Thunnus thynnus (Osteichthyes: Thunnidae), in the Mediterranean Sea. J Appl Ichthyol 25:38-45

Santos MB, Clarke MR, Pierce GJ (2001) Assessing the importance of cephalopods in the diets of marine mammals and other top predators: problems and solutions. Fish Res 52:121-139

Sanz Brau A (1990) Sur la nourriture des jeunes thons rouge Thunnus thynnus (L. 1758) des cotes du golfe de Valence. Rapp Comm Int Mèdit 32:274

Sanzo L (1932) Uova e primi stadi larvali di tonno (Orcynus thynnus Ltkn.). Mem R Com Talass Ital 189:1-16

Sarà G, Sarà R (2007) Feeding habits and trophic levels of bluefin tuna Thunnus thynnus of different size classes in the Mediterranean Sea. J Appl Ichthyol 23:122-127

Sella M (1924) Caratteri differenziali di giovani stadi di Orcynus thynnus Ltkn., O. alalonga Risso, Auxis bisus Bp. Rendic Accad Lincei, serie 5, 33:300-305

Sella M (1929) Migrazioni e habitat del tonno (Thunnus thynnus L.) studiati col metodo degli ami, con osservazioni sull'accrescimento, sul regime delle tonnare ecc. Mem R Com Talass Ital 156:511-542

Sinopoli M, Pipitone C, Campagnuolo S, Campo D, Castriota L, Mostarda E, Andaloro F (2004) Diet of young-of-the-year 
bluefin tuna, Thunnus thynnus (Linnaeus, 1758), in the southern Tyrrhenian (Mediterranean) Sea. J Appl Ichthyol 20:310-313

Tsuji S, Nishikawa Y, Segawa K, Hiroe Y (1997) Distribution and abundance of Thunnus larvae and their relation to the oceanographic condition in the Gulf of Mexico and the Mediterranean Sea during May through August of 1994. ICCAT Col Vol Sci Pap 46:161-176

Tuset VM, Lombarte A, Assis CA (2008) Otolith atlas for the western Mediterranean, north and central eastern Atlantic. Sci Mar 72S1: $1-203$

Vercelli F (1925) Crociere per lo studio dei fenomeni dello Stretto di Messina. I. Il regime delle correnti e delle maree nello Stretto di
Messina. Commissione Internazionale del Mediterraneo, Venezia, Grafiche Ferrari, pp 209

Whitehead PJP, Bauchot ML, Hureau JC, Nielsen J, Tortonese E (eds) (1984-1986). Fishes of the North-eastern Atlantic and Mediterranean. UNESCO, Paris. vol I, II, III

Young RE, Vecchione M, Mangold KM (2010) Cephalopoda Cuvier 1797. Octopods, squids, nautiluses, etc. Version 03 May 2010. http://tolweb.org/Cephalopoda/19386/2010.05.03 in The Tree of Life Web Project, http://tolweb.org/ 